\title{
Transmission of pathogens within the commonly consumed vegetables: Bangladesh perspective
}

\author{
Farahnaaz Feroz ${ }^{1}$ and Rashed Noor ${ }^{2} *$ \\ ${ }^{1}$ Department of Microbiology, Stamford University Bangladesh, 51 Siddeswari Road, Dhaka 1217, Bangladesh \\ ${ }^{2}$ School of Life Sciences (SLS), Independent University, Bangladesh (IUB), Plot 16, Block B, Aftabuddin Ahmed \\ Road, Bashundhara, Dhaka 1229, Bangladesh
}

Received 10 September 2018/Accepted 10 October 2018

\begin{abstract}
Fresh vegetables and fruits are prime source of fiber, vitamins and minerals in our daily diet. Nevertheless, raw vegetables act as a vector for transmitting pathogenic microbes and the majority of diseases are spread by the fecal-oral route at different point of harvesting, post harvesting, during transportation and storage conditions. Contaminated water, carrier materials, and unhygienic handlers are the crucial gateway for disease causing microbes in fresh vegetables. Recently Listeria spp., E. coli, and Salmonella spp. associated outbreak evident in mixed vegetables salad and other vegetable samples also showed pathogenic proliferation to some extent. Children are the major risk group and according to World Health Organization, their mortality rate is high due to food borne infections. In Bangladesh, the situation is more alarming in terms of pathogenic proliferation in raw vegetables. A lot of researches have been conducted in recent years on fresh vegetables and a wide range of vegetables are found to harbor pathogenic microorganisms inclusive of drug resistant bacteria which may affect the measures to combat harmful pathogens. Additionally, phytotoxic, natural contaminants and pesticides are also found to reside in raw vegetables which may be life threatening for both human and animal health as these particles magnify when we repeatedly consume them. The current review focus on the possible intervention of potential contaminants in the vegetable items and possible public health risks associated with their consumption along with a general guideline to combat contamination of fresh vegetables.
\end{abstract}

Key words: Vegetables; Microbial contamination; Transmission; Pathogens

\section{BACKGROUND: NUTRITION \& INFECTION RISK}

A healthy human diet requires a considerable intake of vegetables due to the obvious benefits it can posses; many developed countries have advocated the daily consumption of substantial amounts of fruits and vegetables as a necessity for maintaining good health (1-3).Vegetables are known to be the most important basis of nutrients, dietary fiber, vitamins and minerals (4). A side from the health benefits, ironically, the increased consumption of fruits and vegetables has contributed to lowering the risk of various chronic diseases including enteric diseases, cardiovascular diseases and even of the onset of cancer (5-10).

\section{VEGETABLES AND FOOD SAFETY}

Contamination with both microorganisms such as Listeria monocytogenes, Salmonella enterica, and

*Corresponding Author: Mailing address. Dr. Rashed Noor, Associate Professor, School of Life Sciences (SLS), Independent University, Bangladesh (IUB), Plot 16, Block B, Aftabuddin Ahmed Road, Bashundhara, Dhaka 1229, Bangladesh; E-mail: rashednoor@iub.edu.bd.
Escherichia coli O157:H7 and chemicals are a long term concern in food safety resulting in disease outbreaks (4, 11-14). Vegetables, particularly raw vegetables, have previously been identified as a vehicle for the transmission of various bacterial, viral and parasitic pathogens (3). Contamination with microorganisms can occur during harvesting, post-harvest, handling or distribution leading to an increase in the incidence of foodborne illnesses due to fruits and vegetables $(3,4,8$, $15,16)$. Salad vegetables have long been held responsible for traveler's diarrhea, affecting those who travel to developing countries (17).

Fruits and vegetables along with the agricultural soils may often harbor natural contaminants like mycotoxins (18). Plants may produce toxins (like the Cry proteins, produced by the soil bacterium Bacillus thuringiensis), which are retained within the vegetables for the further uptake by insects (19). Other major plant generated toxins may include phytohaemagglutinin, for red Kidney beans, solanines, for tomato and potato, and for oxalates (spinach and rhubarb) (20-22). Although washing can be applied to remove these contaminant, in order to further ensure the complete removal of the toxins, the regulatory 
bodies like the Center for Disease Control and Prevention (CDC), US Food and Drug Administration (FDA), World Health Organization (WHO) and Center for Science in the Public Interest (CSPI) need to instill the relevant monitoring programs which may include the dietary studies focused to maintain safe and tolerable levels of the natural contaminants $(14,23,24)$.

\section{PATHOGENIC BACTERIA ASSOCIATED WITH VEGETABLES AND THE FATALITY}

The prevalence of the endophytic cultivable bacterial community like Salmonella spp., Escherichia coli, Bacillus cereus, Campylobacter spp., Yersinia enterocolitica, Listeria monocytogenes, Clostridium botulinum, yeasts, molds, some viruses and parasites in the salad vegetables like carrots, cucumbers, tomatoes or onions are not unlikely $(22,25-27)$. The incidents of Listeriosis, the E. coli 0157 outbreak, and the Salmonella outbreak upon consumption of mixed salad vegetables unfortunately seem to be common (23). As mentioned in the earlier reports, besides the potential health offers from the fresh vegetables, the point of safety and the quality of vegetables is of clinical significance due to an array of disease outbreaks (23). The role of the opportunistic pathogens in vegetables contamination conferring the disease outbreak is also well known (26). The World Health Organization (WHO) has long before recognized foodborne illnesses as a major contributor of death, particularly in children (28). Along with WHO, the U.S. Food and Drug Administration (FDA), the U.S Department of Agriculture (USDA), and the Center for Disease Control and Prevention (CDC) suggested that the Good Agricultural practices (GAP) program in combination with the Hazard Analysis and Critical Control Point (HACCP) program would be the most effective means of ensuring food safety of produce at all stages (29).

\section{PREVALENCE OF DRUG -RESISTANT PATHOGENS WITHIN THE VEGETABLES AND THE ASSOCIATED HEALTH IMPACT}

Besides the clinical samples, an array of foods and environmental sources may disseminate the huge number of microorganisms that are deliberately resistant to one or more antimicrobial drugs targeted for medicinal usage or in the agriculture $(30,31)$. Indeed, the problems of anti-microbial resistance is already established globally problem including the cases of multi-drug resistance and the extensively drug resistance (31-33). Eventually, such rise in the drug resistance has greatly limited the spectrum of antibiotics available for the use as treatment of medical complications by the healthcare professionals which in turn, often results in the usage of multiple drugs with high potency that are more expensive and may trigger the physiological side effects as well (34-37). It also affects the supportive care that the patient may receive and often increase the risk of death. As noticed from our previous research, the issue of drug resistance or the multi- drug resistance has been found to be very much conjoint within the pathogenic isolates from the vegetables $(15,29)$. As can be inferred from the previous researches, the widespread and indiscriminate use of antibiotics including the addition of antibiotics to livestock feed has led to the development of serious problems of resistance and hence limits the usefulness of antibiotics to eliminate bacterial infections (38). Dissemination of the antibiotic resistance genes $(s u l \mathrm{I}$, tet $\mathrm{G}, \operatorname{tet} \mathrm{C}, \operatorname{tet} \mathrm{A}$, and tet $\mathrm{M})$ may be triggered even by planting in the manure-amended soils (38).

\section{MICROBIOLOGICAL STUDY OF VEGETABLES IN BANGLADESH}

Proliferation of microorganisms are very much likely (1) to edge the shelf life of vegetables; and (2) to spread and transmit diseases in humans and animals $(15,39)$. Several of our research reported huge contaminating bacteria (including the drug-resistant ones) among a range of vegetables (carrot, lettuce, cucumber, tomato, chilli, onion, capsicum and coriander) collected from different sources $(8,27,39)$. This is to be added that together with our microbiological investigations focusing on the quality of vegetables, we have also introduced the concept and application of microbiological challenge tests (MCT) which goes a long way to unravel how the inoculum size, types of vegetables, and the other physicochemical factors may influence the growth and survival of bacterial pathogens within vegetables commonly consumed (15, 40, 41)

As stated earlier, the microbiological load of vegetables has continued to be an interesting research topic in both Bangladesh and abroad as it has proven itself as the cause of various outbreaks of food borne illnesses (42). Food and water has always been a common vehicle of transmission for infectious diseases, and recent research has identified them as the most important vehicles for the transmission of cholera (44). Although, parasites responsible for food borne diseases are not given that much importance in developing countries, due to the possibility of contamination of vegetables in the field, unhygienic practices or from the use of contaminated wash water (43). Studies conducted by Ali et. al. (43) have been able to identify around $2 \times 10^{4}$ to $2 \times 10^{7} \mathrm{cfu} / \mathrm{g}$ in raw vegetables in Dhaka city, among which paratyphi $A$, Salmonella and Enterobacter were most common. Nawas et al. (44) found counts of Vibrio spp. in salad vegetables from the restaurants of Chittagong ranging from $1.86 \times 10^{4}$ 
to $7.28 \times 10^{5} \mathrm{cfu} / \mathrm{g}$. There were more than 1100 coliforms found in salad samples, among them Salmonella spp., Vibriospp. and Proteus spp. were more commonly identified (44). Other studies in Chittagong have identifies viable bacterial colonies ranging from $2.5 \times 10^{3}$ to $3 \times 10^{6} \mathrm{cfu} / \mathrm{g}$ (42).

\section{CONCLUSION}

The rise in consumption and export of fruits and vegetables has contributed to the spread and rise of food-borne diseases. Several studies have been able to identify large numbers of bacteria and fungus in raw fruits and vegetables. A surpass perception on fruits and vegetables, microbiological invasion of those fresh foods together with the associated environmental triggers, the processing and handling factors of the food items, and the other factors facilitating the microbiological contamination may allocate the remedies to fight against the risk of contamination of these commonly consumed food items. Measures should be taken control the spread of these pathogens, which include removal of pathogen and introduction of key food safety skills among those who handle foods. A united approach to combating the spread of food-borne disease will have a lasting positive impact on consumer safety.

\section{REFERENCES}

1. Locke A, Schneiderhan J, Zick SM. 2018. Diets for health: Goals and guidelines. Am Fam. Physician. 97 (11): 721-728.

2. Wiseman MJ. 2018. Nutrition and cancer: prevention and survival. Br. J. Nutr. 14: 1-7.

3. Abadias M., Usal J, Anguera M, Solsona C, Vinas I. 2008. Microbiological quality of fresh, minimally processed fruit and vegetables, and sprouts from retail establishments. Intl. J. Food Microbiol. 123: 121129

4. Pezzuto A, Belluco S, Losasso C, Patuzzi I, Bordin P, Piovesana A, et al. 2016. Effectiveness of washing procedures in reducing Salmonella enterica and Listeria monocytogenes on a raw leafy green vegetable (Eruca vesicaria). Front. Microbiol. 7: 1663.

5. Tango CN, Wei S, Khan I, Hussain MS, Kounkeu PN, Park JH, et al. 2018. Microbiological quality and safety of fresh fruits and vegetables at retail levels in Korea. J. Food Sci. 83 (2): 386-392.

6. Wadamori Y, Gooneratne R, Hussain MA. 2017. Outbreaks and factors influencing microbiological contamination of fresh produce. J. Sci. Food Agric. 97 (5): 1396-1403.

7. Rahman H, Feroz F, Alam MS, Das KK, Noor, R. 2016. Demonstration of the source of microbial contamination of freshly cultivated cabbage, cauliflower, potato and squash collected from rural farms of Bangladesh. Int. Food. Res. J. 23 (3): 1289-1295.

8. Alam MS, Feroz F, Rahman H, Das KK, Noor R. 2015. Microbiological contamination sources of freshly cultivated vegetables. Nutn. Food. Sci. 45 (4): 646 - 658 .

9. Francis GA, Gallone A, Nychas GJ, Sofos JN, Colelli G, Amodio ML, et al. 2012. Factors affecting quality and safety of fresh-cut produce. Crit. Rev. Food Sci. Nutr. 52 (7): 595-610.

10. Berger CN, Sodha SV, Shaw RK, Griffin PM, Pink D, Hand P, et al. 2010. Fresh fruit and vegetables as vehicles for the transmission of human pathogens. Environ. Microbiol. 12 (9): 2385-97.

11. Denis N, Zhang H, Leroux A, Trudel R, Bietlot H. 2016. Prevalence and trends of bacterial contamination in fresh fruits and vegetables sold at retail in Canada. Food Control. 67: 225-234.

12. Herman KM, Hall AJ, Gould LH. 2015. Outbreaks attributed to fresh leafy vegetables, United States, 1973-2012. Epidemiol. Infect. 143 (14): $3011-3021$.
13. EFSA. 2015. The European union summary report on trends and Sources of zoonoses, zoonotic agents and food-borne outbreaks in 2014. EFSA J. 13 (12): 4329

14. World Health Organization (WHO) \& Food and Agriculture Organization (FAO). 2008. Microbiological hazards in fresh fruits and vegetables. FAO. USA.

15. Noor R, Feroz F. 2017. Food safety in Bangladesh: A microbiological perspective. Stam. J. Microbiol. 6 (1): 1-6.

16. Islam M, Hossain A, Munshi MK, Afifa K, Hossain MA, Noor $R$, Roksana H. 2016. Microbial status of street vended fresh-cut fruits, salad vegetables and juices in Dhaka city of Bangladesh. Int. Food Res. J. 23 (5): 2258-2264.

17. Beuchat LR. 1996. Pathogenic microorganisms Associated with Fresh produce. J. Food prot. 59 (2): 204-216.

18. Schenzel J, Forrer HR, Vogelgsang S, Hungerbühler K, Bucheli TD 2012. Mycotoxins in the environment: Production and emission from an agricultural test field. Environ. Sci. Technol. 46 (24): 13067-75.

19. Souza CSF, Silveira LCP, Paula DP, Andow DA, Mendes SM. 2018 Transfer of Cry1F from $B t$ maize to eggs of resistant Spodoptera frugiperda. PLoS ONE. 13 (9): e0203791.

20. Nakayasu M, Umemoto N, Ohyama K, Fujimoto Y, Lee HJ, Watanabe B, et al. 2017. A dioxygenase catalyzes steroid $16 \alpha$-hydroxylation in steroidal glycoalkaloid biosynthesis. Plant Physiology. 175 (1): 120-133.

21. Kumar S, Verma AK, Sharma A, Kumar D, Tripathi A, Chaudhari BP, et al. 2013. Phytohemagglutinins augment red kidney bean (Phaseolus vulgaris L.) induced allergic manifestations. J. Proteomics. 20 (93): 50-64.

22. Albersmeyer M, Hilge R, Schröttle A, Weiss M, Sitter T, Vielhauer V. 2012. Acute kidney injury after ingestion of rhubarb: secondary oxalate nephropathy in a patient with type 1 diabetes. BMC Nephrology. 13: 141.

23. Nithya A, Babu S. 2017. Prevalence of plant beneficial and human pathogenic bacteria isolated from salad vegetables in India. BMC Microbiol. 17 (1): 64 .

24. Wu JC, Lai CS, Tsai ML, Ho CT, Wang YJ, Pan MH. 2017. Chemopreventive effect of natural dietary compounds on xenobiotic-induced toxicity. J. Food Drug. Anal. 25 (1): 176-186

25. Mogren L, Windstam S, Boqvist S, Vågsholm I, Söderqvist K, Rosberg AK, et al. 2018. The hurdle approach-a holistic concept for controlling food safety risks associated with pathogenic bacterial contamination of leafy green vegetables. a review. Front. Microbiol. 24 (9): 1965.

26. Al-Kharousi ZS, Guizani N, Al-Sadi AM, Al-Bulushi IM, Shaharoona B 2016. Hiding in fresh fruits and vegetables: opportunistic pathogens may cross geographical barriers. Int. J. Microbiol. 2016: 1-14.

27. Rahman F, Noor R. 2012. Prevalence of pathogenic bacteria in common salad vegetables of Dhaka Metropolis. Bangladesh J. Bot. 41 (2): 159-162.

28. Adak GK, Meakins SM, Yip H, Lopman BA, O'Brien SJ. 2005. Disease risks from foods, England and Wales, 1996-2000. Emerg. Infect. Dis. 11: 365-372.

29. Izumi H. 2010. Microbiological safety of fresh produce from the farm - to table food chain. Mem. Faculty. B. O. S. T. Kinki Uni. 26: 3-11.

30. Rasheed MU, Thajuddin N, Ahamed P, Teklemariam Z, Jamil K. 2014 Antimicrobial drug resistance in strains of Escherichia coli isolated from food sources. Revista do Instituto de Medicina Tropical de Sao Paulo. 56 (4): 341-

31. Dutta S, Hassan MR, Rahman F, Jilani MSA, Noor R. 2013. Study of antimicrobial susceptibility of clinically significant microorganisms isolated from selected areas of Dhaka,Bangladesh . Bangladesh J. Med. Sci. 12 (1):3442

32. Aurin TH, Munshi SK, Kamal SM, Rahman MM, Hossain MS, Marma T, et al. 2014. Molecular approaches for detection of the multi-drug resistant tuberculosis (MDR-TB) in Bangladesh. PLoS One 9 (6): e99810.

33. Noor R, Akhter S, Rahman F, Munshi SK, Kamal SM, Feroz F. 2013. Frequency of extensively drug-resistant tuberculosis (XDR-TB) among retreatment cases in NIDCH, Dhaka, Bangladesh. J. Infect. Chemother. 19 (2): 243-8.

34. Hasan R, Acharjee M, Noor R. 2016. Prevalence of vancomycin resistant Staphylococcus aureus (VRSA) in methicillin resistant $S$. aureus (MRSA) strains isolated from burn wound infections. Tzu Chi Med. J. 28 (2): 49-53.

35. Noor R, Munna MS. 2015. Emerging diseases in Bangladesh: current microbiological research. Tzu Chi Med. J. 27 (2): 49-53.

36. Khan SA, Feroz F, Noor R. 2013. Study of extended spectrum $\beta$-lactamase producing bacteria from urinary tract infection in Dhaka city, Bangladesh. Tzu Chi Med. J. 25 (1): 39-42.

37. Noor R, Shams F, Munshi SK, Rahman MM, Noor R. 2013. Prevalence and antibiogram profile of uropathogens isolated from hospital and community patients with urinary tract infections in Dhaka city. J. Ban. Aca Sci. 37 (1): 57-63.

38. Wang FH, Qiao M, Chen Z, Su JQ, Zhu YG. 2015. Antibiotic resistance genes in manure-amended soil and vegetables at harvest. J. Hazard Mater. 
299: 215-21.

39. Noor R, Malek M, Rahman MS, Meghla M, Acharjee M, Rahman MM. 2015. Assessment of survival of pathogenic bacteria in raw fresh vegetables through in vitro challenge test. Int. J. Food Cont. 2: 15.

40. Feroz F, Senjuti JD, Noor R. 2013. Determination of microbial growth and survival in salad vegetables through in vitro challenge test. Int. J. Nut. Food Sci. 2 (6): 312-319.

41. Noor R, Feroz F. 2015. Requirements for microbiological quality management of the agricultural products: An introductory review in Bangladesh perspectives. Nutn. Food Sci. 45 (5): 808-816.
42. Nipa M, Mazumdar RM, Hasan MH, Fakruddin M, Islam S, Bhuiyan HR, et al. 2011. Prevalence of multi drug resistant bacteria on raw salad vegetables sold in major markets of Chittagong city, Bangladesh. Middlle East J. Sci. Res. 10 (1): 70-11.

43. Ali Q, Elahi M, Ahsan M, Tahir MHN, Khaliq I, Kashif M et al. 2012. Genetic analysis of morpho-physiological and quality traits in chickpea genotypes (Cicer arietinum L.) African J. Agri. Res.7 (23): 3403-3412.

44. Nawas T, Mazumdar RM, Das S, Nipa M, Islam S, Bhuiyan HR, et al. 2012. Microbiological quality and antibiogram of E. coli, Salmonella and Vibrio of salad and water from restaurants of Chittagong. J. Environ. Sci. Nat. Resources. 5 (1): 159-166. 